\title{
Proceedings of the Annual Meeting of the Georgia Association of Mathematics Teacher Educators
}

2008

\section{Becoming Critical Mathematics Pedagogues: A Journey}

David W. Stinson

Georgia State University, dstinson@gsu.edu

DOI

10.20429/gamte.2008.020102

Follow this and additional works at: https://digitalcommons.georgiasouthern.edu/gamte-proceedings

Part of the Mathematics Commons, and the Teacher Education and Professional Development Commons

\section{Recommended Citation}

Stinson, David W. (2008) "Becoming Critical Mathematics Pedagogues: A Journey," Proceedings of the Annual Meeting of the Georgia Association of Mathematics Teacher Educators: Vol. 2 : Iss. 1 , Article 2. DOI: $10.20429 /$ gamte.2008.020102

Available at: https://digitalcommons.georgiasouthern.edu/gamte-proceedings/vol2/iss1/2

This article is brought to you for free and open access by the Journals at Digital Commons@Georgia Southern. It has been accepted for inclusion in Proceedings of the Annual Meeting of the Georgia Association of Mathematics Teacher Educators by an authorized administrator of Digital Commons@Georgia Southern. For more information, please contact digitalcommons@georgiasouthern.edu. 
Becoming Critical Mathematics Pedagogues: A Journey

\author{
David W. Stinson, Carla R. Bidwell, Ginny C. Powell, Mary M. Thurman \\ Georgia State University \\ dstinson@gsu.edu
}

\begin{abstract}
This session will report the findings of a study that explored the beginning transformations in the pedagogical philosophies and practices of three mathematics teachers (middle, high school, and 2-year college) who completed a graduate-level mathematics education course that focused on critical theory and teaching for social justice, and how these transformations are compatible (or not) with reform mathematics education as suggested by the National Council of Teachers of Mathematics (NCTM), and in turn, the new Georgia Performance Standards (GPS). The study employed Freirian participatory research methodology; in fact, the participants were not only coresearchers, but also co-authors of the study. Data collection included reflective essays, journals, and "storytelling"; data analysis was a combination of textual analysis and autoethnography. The findings report that the teachers believed that the course provided not only a new language but also a legitimization to transform their pedagogical philosophies and practices away from the "traditional" and toward a mathematics for social justice - a mathematics that is, indeed, compatible with the reform movements of the NCTM and GPS.
\end{abstract}




\section{Becoming Critical Mathematics Pedagogues: A Journey}

Since 1989 the National Council of Teachers of Mathematics (NCTM) has argued not only for instruction in mathematical content standards, but also for instruction in mathematical process standards (NCTM, 1989, 2000). The NCTM's, and in turn, the Georgia Performance Standards (GPS; see http://www.georgiastandards.org/math.aspx), recommendation of blending content and process standards throughout mathematics instruction requires the development of a different mathematics classroom-different from the "traditional" mathematics classroom found in most U.S. schools (see Hiebert, 2003, for a discussion of the traditional curricula and pedagogy in the mathematics classroom). In this different mathematics classroom, students are no longer passive, empty depositories awaiting the teacher's deposits - what Freire (1970/2000) coined, "the 'banking' concept of education" (p. 72) - but are active co-creators of classrooms "where students of varied backgrounds and abilities work with expert teachers, learning important mathematical ideas with understanding, in environments that are equitable, challenging, supportive, and technologically equipped for the twenty-first century" (NCTM, 2000, p. 4). These co-created classrooms, if desired, can set in motion a different mathematics pedagogy - a mathematics pedagogy positioned within critical theory.

Just as the NCTM (and GPS) recommends, mathematics pedagogy positioned within critical theory blends content and process standards throughout mathematics instruction in cocreated classrooms; it differs, however, in that critical mathematics pedagogy centers instruction specifically around issues of social and political justice and reform (e.g., see Frankenstein, 1987, 1990, 1995; Gutstein, 2003, 2006, 2007; Gutstein \& Peterson, 2005; Skovsmose, 1994, 2005). In other words, knowledge and understanding of mathematics from the perspective of critical pedagogy is understood as a means for student (and teacher) self-empowerment to organize and reorganize interpretations of social institutions and traditions, and to develop proposals for more just and equitable social and political reform (Skovsmose, 1994).

Although the concept of teaching for "social justice" is increasingly being emphasized in teacher education programs as part of teachers' overall "diversity" or "multicultural" initial preparation or professional development (McDonald, 2007), there is much less emphasis on how teaching for social justice - or critical pedagogy more generally — might be included in the preparation and development of mathematics teachers. For the most part, the mathematics education literature has reported the teaching practices of exemplar critical mathematics pedagogues (e.g., Marilyn Frankenstein, Eric Gutstein, and Ole Skovsmose). There is a scarcity of literature that has reported how mathematics teacher educators and/or programs might assist in developing critical mathematics teachers who teach for social justice (e.g., see Bartell, 2005).

Therefore, the purpose of this study (briefly summarized here) was to explore the transformations in the pedagogical philosophies and practices of three mathematics teachers (middle, high school, and 2-year college) who completed a graduate-level, critical mathematics education course that had the intended goal of assisting in the development of critical mathematics teachers. The study, however, was not about "teacher change" per se; we understand teacher change to be a complex endeavor (e.g., see Brown \& Borko, 1992; Fennema $\&$ Nelson, 1997). In other words, we acknowledge effective mathematics teacher change most often occurs when teacher professional development opportunities are long-term, school-based efforts conducted within a community of learners that provide teachers opportunities to grapple with significant mathematics and to consider how students might engage with that mathematics (Mewborn, 2003). However, like the NCTM Principles and Standards (2000), we believe that 
teaching is a continual journey; in that, effective teachers do not "master" teaching, but rather find themselves in a continuous state of growth and change (Mewborn, 2003). Or, said in another way, effective teachers find themselves in a continuous state of becoming.

Building upon Bakhtin's concepts "ideological selves" and "ideological becoming," Gomez, Black, and Allen (2007) developed the idea of "'becoming' a teacher” (p. 2108). The concept ideological self acknowledges individuals as socially determined persons who view the world through a system of ideas that are mediated through language and experiences; whereas, the concept ideological becoming positions socially determined persons within continual conflicts and struggles as they come into contact with different ideological world views. Hence, becoming a teacher, as described by Gomez et al., is a process that is never finalized or fixed but rather a fluid process of continuous critical examination of self and students (and curriculum) in which old ways of thinking and acting are disrupted and transformed into new ways of thinking and acting - ways that hopefully are more ethical and just. It is within the context of becoming that the following three questions guided the study: (a) How did the teachers' beginning transformations change (or not) their philosophies of mathematics teaching and learning? (b) How did the teachers' beginning transformations change (or not) their classroom teaching practices? (c) How did the teachers' beginning transformations change (or not) their students' actions and learning?

Theoretical Framework

Critical theory provided the underlying theoretical framework for the study. The origin of critical theory is associated with the Frankfurt School (circa 1920), which holds a Marxist theoretical perspective: to critique and subvert domination in all its forms (Bottomore, 1991). Included in these critiques is an examination of how social interests, conflicts, and contradictions are expressed in thought and produced and reproduced in systems of domination (Bottomore, 1991). Critical theorists contend that an examination of these systems of domination will bring about an awakening of consciousness and awareness of social injustices, motivating selfempowerment and social transformation.

The concepts of self-empowerment and social transformation are reoccurring themes found in the scholarship of a contemporary critical theorist, Paulo Freire (e.g., see 1970/2000). Freire's literacy scholarship (but not limited to literacy) advocates a critical, dialectical reading of the word and world, so as to write the word to rewrite the world. It is his scholarship and his popularization of the concept of conscientização - "learning to perceive social, political, and economic contradictions, and to take action against the oppressive elements of reality" (Freire, 1970/2000, p. 35) - that provides, to a certain extent, the foundation for critical pedagogy. In the most general sense, critical pedagogy supports pedagogical theories and practices that encourage both teachers and students to develop an understanding of the interconnecting relationship among ideology, power, and culture and rejects any claim to universal foundations for truth and culture, as well as any claim to objectivity (Leistyna \& Woodrum, 1996).

Critical pedagogy enacted in the mathematics classroom, by and large, adopts the pedagogical theories and practices of critical pedagogy, while explicitly using mathematics as an analytical tool for examining social injustices. Or more specifically, critical mathematics pedagogy is teaching mathematics for social justice. Gutstein (2006) noted that teaching mathematics for social justice has two dialectically related sets of pedagogical goals: one set focuses on social justice and the other set focuses on mathematics. Building from Freire's literacy scholarship, the social justice pedagogical goals are reading the world with mathematics, writing the world with mathematics, and developing positive cultural and social identities 
(Gutstein, 2006). The mathematics pedagogical goals are reading the mathematical word, succeeding academically in the traditional sense, and changing students' (and teachers') orientation to mathematics (Gutstein, 2006).

Method

Grounded in critical inquiry (Crotty, 1998) and participatory action research (Kemmis \& Wilkinson, 1998), the methodology employed in the study was Freirian empowering research (Lather, 1986). The goal of Freirian research is to blur the distinction between research, learning, and action by providing the researcher and the participants opportunities to collectively engage in the struggle toward social justice; it encourages researcher-participant reciprocity, turning participants into co-researchers (and in this case, co-authors as well) while providing the means for researcher and participants' self-empowerment (Lather, 1986).

The participants were selected from a group of 19 graduate students who completed a graduate-level course (spring 2006) entitled Topics in School Mathematics Curriculum: Critical Theory and Teaching for Social Justice. Three students were selected purposively as participants in order that a mathematics teacher representing middle, high school, and college would be included in the study. Data collection consisted of four artifacts written by the three participants: two written assignments from the course, reflective response essays written 3 months after the course, and autoethnographic "storytelling" narratives (Ellis \& Bochner, 2000) written 9 months after the course. The artifacts from the course were reading journals and academic essays submitted by each participant. The third artifact, the response essay written 3 months after the course, asked each participant to respond to the three research questions of the study.

The fourth artifact, written 9 months after the course, was an autoethnographic narrative detailing each participant's experiences in planning and implementing a specific mathematics for social justice lesson within her respective classroom. Mary (middle school) and Carla (high school) used data about the "race" of people pulled over by police. Students used bar charts, boxand-whisker plots, and descriptive statistics to examine whether the data indicated racial profiling had taken place. Ginny (2-year college) used historical minimum-wage data, and students used regression to fit curves to the data and advocate for or against a raise in the minimum wage, and its amount.

\section{Discussion of Findings}

Throughout the collective autoethnographic narratives and textual data, the three teachers (i.e., participants, co-researchers, and -authors) articulated what it was like to attempt a new, different kind of mathematics teaching, one based in critical pedagogy. But this is a journey, not a destination. Mary, describing her critical pedagogical journey, declared: "Teachers must reflect on where they have been to see where they are going" (Academic Essay). Carla wrote, "I am trying to make the move toward a more democratic classroom where my students' voices are heard, their cultures have value, and everyone in the class is both a teacher and learner" (Response Essay). Ginny articulated her journey as developing a new way of life rather than a mere method of teaching: "Critical...[pedagogy] is about questioning everything, from the foundations of mathematics itself to every practice and belief. It is a way of life rather than a method of teaching. ...I now find myself second-guessing everything I do, everything I plan, even my word choice in real time as I stand before a class" (Response Essay).

As each teacher spoke about her journey, each also noted that she had begun her teaching career with a more or less "traditional" belief structure about mathematics teaching and learning. Over the years, however, as experienced mathematics teachers, with several years of teaching experience, each had began to recognize that traditional practices were not working for every 
student - or for most students. Individually and collectively, they believed that their participation in the critical theory and teaching mathematics for social justice course provided them with a new language that assisted them in communicating and acting on what they were already thinking about mathematics teaching and learning. Carla wrote, "I realize now that 5 years ago I was already thinking like a critical theorist, I just didn't have a clue what that was" (Response Essay). Ginny echoed and extended Carla's remark, writing: "I began to grow on my own toward a more student-centered, equitable style, though I did not have the words for it or the feeling that what I was doing was being done elsewhere or would be respected by others" (Response Essay).

Effectively, this new language brought confirmation to what the teachers were, through their years of teaching experience, beginning to understand: "Unless educational methods are situated in the students' cultural experiences, students will continue to show difficulty in mastering content area that is not only alien to their reality, but is often antagonistic toward their culture and lived experiences" (Bartolomé, 1996, p. 249). Or said in another way, "the only education that can have meaning is education that is personal and therefore political" (Lewis \& Simon, 1996, p. 261). In many ways, the teachers' narratives demonstrate the benefits of experiential learning, as advocated by Dewey (1938/1997). In each of the lessons, knowledge of subject matter - in this case, mathematics - was used to examine or make better sense of the sociopolitical lived experiences of the students (and teachers).

But it is not enough just to present problems based on something known to the students, given that the teachers understood that a fundamental tenet of critical pedagogy is the need to include both teachers' and students' voices and lived experiences in the learning process (Leistyna \& Woodrum, 1996). The challenge for critical pedagogues therefore is how critical pedagogy might be employed to appropriate the more radical and useful aspects of contemporary cultural studies in addressing the different social, political, and economic contexts that are producing students, teachers, classrooms, schools, communities, and so on (Giroux, 1996). In other words, the active participation, interest, reflection, and critical understanding(s) of those taught — and those teaching — are necessary (Dewey, 1937/1987; Freire 1970/2000). The teachers believed that the most satisfying part of teaching mathematics from a critical pedagogical perspective was the conversations with and between their students. These conversations were not only culturally relevant, but personally relevant, even provocative; thus, achieving an essential aspect of social justice mathematics (Gutstein, 2006).

Each of the lessons planned and implemented contained both a personal and political element for students. During Mary's (middle school) and Carla's (high school) lessons in calculating basic statistical analyses of racial profiling data, students shared their personal experiences, both orally and in writing, unveiling the social injustices that occur in their communities - while doing mathematics (Stein, Smith, Henningsen, \& Silver, 2000). For the adults in Ginny's (2-year college) class, most of whom had had some experience working for minimum wage, the lesson planned to determine best-fit functions to minimum-wage data was very personal and led into political discussions as midterm elections were approaching. Many students were outraged upon realizing that the minimum wage had not changed in 10 years. In co-created classrooms like these, where content and process standards are continually integrated, the teachers argued, "once a fabric of relevance has been constructed, content learning naturally follows" (Kincheloe \& Steinberg, 1996, p. 189). Or said in another way, when teachers create learning environments where students, especially those perceived as "low" performing, can demonstrate their possession of knowledge and expertise, they then demonstrate ability and competency (Bartolomé, 1996). In all three of the lessons, the teachers "tapped into" students' 
knowledge that led to them taking personal ownership of the projects - and most important, of the mathematics.

In teaching for social justice, Freire (1970/2000) claimed, "The educator is the students' partner as they engage together in critical thinking and a quest for mutual humanization" (p. 49). Though their students may not have been aware of it, the teachers were engaged in the process of learning as much as the students during the described lessons. The teachers noted that a traditional mathematics classroom typically generates little "new" knowledge for the teacher who is often accustomed to a banking method of teaching (Freire, 1970/2000), but in the lessons described, discussions revealed lived experiences and political opinions that presented both students and teachers with new knowledge. The objective during the socially just lessons was the production of students' and teachers' own ideas and values rather than the mere reproduction of ideas and values of the dominant groups (Leistyna \& Woodrum, 1996), and, most important, using mathematics as a sociopolitical tool to justify and support these newly produced ideas and values (Skovsmose, 1994). Through this new, different way of teaching, students and teachers "develop their power to perceive critically the way they exist in the world with which and in which they find themselves" (Freire, 1970/2000, p. 83).

Teaching mathematics for social justice however asks much of teachers - and studentsand it is not easy. Crotty (1998) claimed, and the teachers' beginning transformations illustrate, that with every action taken, the context changes and one must critique her or his assumptions again and again. But the possible benefits of students and teachers engaging meaningfully with mathematics and transforming into agents of change are worth the work. The teachers believed that they, as well as their students, must "exercise the kind of courage needed to change the social order where necessary" (Giroux \& McLaren, 1996, p. 318). The teachers acknowledged a choice between a pedagogy that accepts the status quo and a pedagogy that seeks to bring about change (Crotty, 1998) - they were committed to choosing the latter.

Since completing the course, and teaching the social justice lessons described, the teachers claimed that they continue to evolve as critical mathematics pedagogues. They actively seek and encourage critical connections with other disciplines. They continue to use the tenets of critical pedagogy in planning curricula, developing classroom environments, and establishing channels of communications. In other words, they have become stronger facilitators of critical mathematical discourse not only with their students, but also with their colleagues.

On the other hand, the teachers also conceded that their pedagogical philosophies had changed faster than their practices - not an uncommon phenomenon among mathematics teachers (e.g., see Wilson \& Goldenberg, 1998). While they all agreed that their classes should be more a conversation between teacher and students (Lerman, 2000) and move away from the "banking" method, they found themselves mired in traditional practices. They noted many constraints that often make it difficult to change their pedagogical practices:

At first I am always met with some student resistance as I encourage my students to become independent thinkers as they work together to discover patterns and formulate conjectures. (Mary's Academic Essay)

My biggest challenge this semester, however, has not been teaching but convincing my colleagues of what to teach and what not to teach. (Carla's Academic Essay) I am limited to single semester, single subject, strictly defined curricula. I am not easily able to do some of the long-term projects. (Ginny's Academic Essay)

Furthermore, Mary and Carla, as Pre-K-12 educators, experienced difficulties implementing social justice lessons into their classrooms while at the same time undergoing state curriculum 
reform (i.e., GPS). Although each teacher discussed a specific constraint, each felt she had experienced somewhat similar constraints that prevented her from making the change more quickly. But then again, all three teachers also asserted that they would be diligent in developing methods that overcome or undercut these constraints as they continue to establish the tenets of critical pedagogy as integral components of their pedagogical philosophies and practices.

Conclusions

The study began with three questions in mind: how did exposure to critical pedagogy begin a transformation (or not) of the teachers' philosophies of mathematics teaching and learning, their classroom teaching practices, and their students' learning. With regard to their philosophies, it is not so much that their philosophies changed, but that they now have a name for what they were already thinking. And once it was named, their way of thinking gained legitimacy in their eyes, as well as in others' view. The teachers believed that they could stand up proudly and proclaim themselves, through words and actions, as critical mathematics pedagogues, rather than feeling insecure and keeping quiet.

The teachers' mathematics classroom teaching practices have definitely changed. Most important, the teachers' have been given a new "voice." Each teacher felt as though she had already begun a journey toward reform mathematics instruction, but again, critical pedagogy gave her the words and the backing to put her ideas into action. Collectively, the teachers provided specific examples of lesson plans created and implemented using critical pedagogy, but mostly the teachers believed that there have been innumerable instances when their new critical outlook has influenced their choice of words, their decision to allow a discussion to stray from mathematics into something equally meaningful, and a generalized awareness of what was going on in their classroom from more than just a mathematical perspective. The teachers said that their classrooms have become more democratic, inclusive places, with class sessions moving toward a conversation between teacher and students. And perhaps most important, the teachers believed that they have an ongoing sense of constant change and improvement, very different from the traditional idea of there being a "best practice" that a teacher should learn and use forever. In short, each has a sense of becoming.

Their students' learning also has been positively impacted; in that, the students too were given a new voice through the use of critical pedagogy. The students became more engaged with the mathematics and stayed on task during the mathematics projects. Students that normally did not contribute were motivated to participate in classroom discussions. Communication outside of the classroom was opened as well; they talked with their parents about the lesson, they came to office hours, and they attended after-school tutoring sessions. These actions might have been because they found the mathematical topics personally relevant and were able to connect it to their studies in other classes.

For those who believe in the transformative power of critical pedagogy, the significance of the study's conclusions cannot be overstated. There are probably many mathematics teachers out there, like the teachers of this study, afraid to pursue the ideas they have because they lack the language and the legitimization; forced, through lack of knowledge, to reproduce the same traditional mathematics pedagogy they themselves endured. If those teachers could be reached, imagine how many students they could influence. Dewey stated, "If a sufficient number of educators devote themselves to striving courageously and with full sincerity to devote themselves to find the answers to the concrete questions which the idea and the aim put to us, I believe that the question [of education and social change] will cease to be a question, and will become a moving answer in action" (Dewey, 1937/1987, p. 417). Of course, a teacher cannot be 
said to have chosen a method or philosophy of teaching if only one option is offered. Because the teachers now consider themselves becoming critical mathematics pedagogues, they hope that teacher education programs will expose other preservice and inservice teachers to different options, such as critical pedagogy, to move mathematics pedagogy away from the traditionaland toward a pedagogy of social justice.

\section{References}

Bartell, T. G. (2005). Learning to teach mathematics for social justice: Getting personal. Paper presented at the annual meeting of the American Educational Research Association, San Francisco.

Bartolomé, L. I. (1996). Beyond the methods fetish: Toward a humanizing pedagogy. In P. Leistyna, A. Woodrum, \& S. A. Sherblom (Eds.), Breaking free: The transformative power of critical pedagogy (pp. 229-252). Cambridge, MA: Harvard Educational Review.

Bottomore, T. B. (Ed.). (1991). A Dictionary of Marxist thought (2nd ed.). Malden, MA: Blackwell.

Brown, C. A., \& Borko, H. (1992). Becoming a mathematics teacher. In D. A. Grouws (Ed.), Handbook of research on mathematics teaching and learning (pp. 209-239). New York: Macmillan.

Crotty, M. (1998). The foundations of social research: Meaning and perspective in the research process. Thousand Oaks, CA: Sage.

Dewey, J. (1987). Education and social change. In J. A. Boydston (Ed.), John Dewey: The later works, 1925-1953 (Vol. 11, pp. 408-415). Carbondale, IL: Southern Illinois University Press. (Original work published 1937)

Dewey, J. (1997). Experience \& education. New York: Touchstone. (Original work published 1938)

Ellis, C., \& Bochner, A., P. (2000). Autoethnography, personal narrative, reflexivity: Researcher as subject. In N. K. Denzin \& Y. S. Lincoln (Eds.), Handbook of qualitative research (2nd ed., pp. 733-768). Thousand Oaks, CA: Sage.

Fennema, E., \& Nelson, B. S. (Eds.). (1997). Mathematics teachers in transition. Mahwah, NJ: Lawrence Erlbaum Associates.

Frankenstein, M. (1987). Critical mathematics education: An application of Paulo Freire's epistemology. In I. Shor (Ed.), Freire for the classroom: A sourcebookfor liberatory teaching (pp. 180-210). Portsmouth, NH: Boynton/Cook.

Frankenstein, M. (1990). Incorporating race, gender, and class issues into a critical mathematical literacy curriculum. Journal of Negro Education, 59(3), 336-347.

Frankenstein, M. (1995). Equity in mathematics education: Class in the world outside the class. In W. G. Secada, E. Fennema, \& L. B. Adajian (Eds.), New directions for equity in mathematics education (pp. 165-190). Cambridge, UK: Cambridge University Press.

Freire, P. (2000). Pedagogy of the oppressed (M. B. Ramos, Trans.) (30th anniversary ed.). New York: Continuum. (Original work published 1970)

Giroux, H. A. (1996). Doing cultural studies: Youth and the challenge of pedagogy. In P. Leistyna, A. Woodrum, \& S. A. Sherblom (Eds.), Breaking free: The transformative power of critical pedagogy (pp. 83-107). Cambridge, MA: Harvard Educational Review.

Giroux, H. A., \& McLaren, P. (1996). Teacher education and the politics of engagement: The case for democratic schooling. In P. Leistyna, A. Woodrum, \& S. A. Sherblom (Eds.), 
Breaking free: The transformative power of critical pedagogy (pp. 301-331). Cambridge, MA: Harvard Educational Review.

Gomez, M. L., Black, R., W., \& Allen, A.-R. (2007). "Becoming” a teacher. Teachers College Record, 109(9), 2107-2135.

Gutstein, E. (2003). Teaching and learning mathematics for social justice in an urban, Latino school. Journal for Research in Mathematics Education, 34(1), 37-73.

Gutstein, E. (2006). Reading and writing the world with mathematics: Toward a pedagogy for social justice. New York: Routledge.

Gutstein, E. (2007). "And that's just how it starts": Teaching mathematics and developing student agency. Teachers College Record, 109(2), 420-448.

Gutstein, E., \& Peterson, B. (Eds.). (2005). Rethinking mathematics: Teaching social justice by the numbers. Milwaukee, WI: Rethinking Schools.

Hiebert, J. (2003). What research says about the NCTM Standards. In J. Kilpatrick, W. G. Martin, \& D. Schifter (Eds.), A research companion to Principles and Standards for School Mathematics (pp. 5-23). Reston, VA: National Council of Teachers of Mathematics.

Kemmis, S., \& Wilkinson, M. (1998). Participatory action research and the study of practice. In B. Atweh, S. Kemmis, \& P. Weeks (Eds.), Action research in practice: Partnership for social justice in education (pp. 21-36). New York: Routledge.

Kincheloe, J. L., \& Steinberg, S. R. (1996). A tentative description of post-formal thinking: The critical confrontation with cognitive theory. In P. Leistyna, A. Woodblum, \& S. A. Sherblom (Eds.), Breaking free: The transformative power of critical pedagogy (pp. 167195). Cambridge, MA: Harvard Educational Review.

Lather, P. A. (1986). Issues of validity in openly ideological research: Between a rock and a soft place. Interchange, 17(4), 63-84.

Leistyna, P., \& Woodrum, A. (1996). Context and culture: What is critical pedagogy? In P. Leistyna, A. Woodrum, \& S. A. Sherblom (Eds.), Breaking free: The transformative power of critical pedagogy (pp. 1-7). Cambridge, MA: Harvard Educational Review.

Lerman, S. (2000). The social turn in mathematics education research. In J. Boaler (Ed.), Multiple perspectives on mathematics teaching and learning (pp. 19-44). Westport, CT: Ablex.

Lewis, M., \& Simon, R. I. (1996). A discourse not intended for her: Learning and teaching within patriarch. In P. Leistyna, A. Woodrum, \& S. A. Sherblom (Eds.), Breaking free: The transformative power of critical pedagogy (pp. 253-271). Cambridge, MA: Harvard Educational Review.

McDonald, M. (2007). The joint enterprise of social justice teacher education. Teachers College Record, 109(8), 2047-2081.

Mewborn, D. (2003). Teaching, teachers' knowledge, and their professional development. In J. Kilpatrick, W. G. Martin, \& D. Schifter (Eds.), A research companion for NCTM Standards (pp. 45-52). Reston, VA: National Council for Teachers of Mathematics.

National Council of Teachers of Mathematics. (1989). Curriculum and evaluation standards for school mathematics. Reston, VA: National Council of Teachers of Mathematics.

National Council of Teachers of Mathematics. (2000). Principles and standards for school mathematics. Reston, VA: National Council of Teachers of Mathematics.

Silverman, D. (2001). Interpreting qualitative data: Methods for analysing talk, text, and interaction (2nd ed.). Thousand Oaks, CA: Sage. 
Skovsmose, O. (1994). Towards a critical mathematics education. Educational Studies in Mathematics, 27, 35-57.

Skovsmose, O. (2005). Travelling through education: Uncertainty, mathematics, responsibility. Rotterdam, NHL: Sense Publishers.

Stein, M. K., Smith, M. S., Henningsen, M., A., \& Silver, E. A. (Eds.). (2000). Implementing standards- based mathematics instruction: A casebook for professional development. New York: Teachers College Press.

Wilson, M., \& Goldenberg, M. (1998). Some conceptions are difficult to change: One middle school mathematics teacher's struggle. Journal of Mathematics Teacher Education, 1(3), 269-293. 